Guieu Cécile (Orcid ID: 0000-0001-6373-8326)

Azhar Muchamad Al (Orcid ID: 0000-0002-4572-9765)

Aumont Olivier (Orcid ID: 0000-0003-3954-506X)

Mahowald Natalie M (Orcid ID: 0000-0002-2873-997X)

Lévy Marina (Orcid ID: 0000-0003-2961-608X)

Lachkar Zouhair (Orcid ID: 0000-0001-7881-1987)

\title{
Major impact of dust deposition on the productivity of the Arabian Sea
}

\author{
Cécile Guieu ${ }^{1,2,}$ Muchamad Al Azhar ${ }^{2,3}$, Olivier Aumont ${ }^{4}$, Natalie Mahowald ${ }^{5}$, Marina \\ Levy ${ }^{4}$, Christian Ethé ${ }^{4}$, Zouhair Lachkar ${ }^{2}$
}

${ }^{1}$ Sorbonne Université, CNRS, Laboratoire d'Océanographie de Villefranche, LOV, F-06230,

Villefranche-sur-mer, France.

${ }^{2}$ The Center for Prototype Climate Modeling, New York University in Abu Dhabi, Abu

Dhabi, UAE

${ }^{3}$ Plymouth Marine Laboratory, Prospect Place, The Hoe, Plymouth PL1 3DH, UK

${ }^{4}$ Sorbonne Université, CNRS/IRD/MNHN, Laboratoire d'Océanographie et de Climatologie:

Expérimentation et Approches Numériques, LOCEAN-IPSL, F-75005 Paris, France

${ }^{5}$ Department of Earth and Atmospheric Sciences, Cornell University, Ithaca, NY, 14853,

USA

1. Atmospheric iron deposition is essential to sustain the high levels of productivity during the summer monsoon

2. Nitrogen fixation remains low despite large iron deposition

3. Atmospheric deposition of nitrogen and phosphorus also play a negligible role

This article has been accepted for publication and undergone full peer review but has not been through the copyediting, typesetting, pagination and proofreading process which may lead to differences between this version and the Version of Record. Please cite this article as doi: $10.1029 / 2019$ GL082770 


\section{Abstract}

In the Arabian Sea (AS), spatio-temporal nutrient limitation patterns of primary production and the possible role of nutrient inputs from the atmosphere are still not well understood. Using a biogeochemical model forced by modelled aerosol deposition, we show that without high atmospheric iron inputs through dust deposition during the summer monsoon, primary production over the AS would be reduced by half. Atmospheric iron deposition also supports most of the nitrogen fixation over the AS. However, our ocean biogeochemistry modelling results suggest that dinitrogen fixation constitutes a negligible fraction of the primary production. Finally, we show that atmospheric inputs of nitrogen, mostly from anthropogenic activities in India, have a negligible impact on primary production.

\section{Plain-Language summary}

Phytoplankton are microscopic organisms that live in watery environments such as the ocean. Like land plants, phytoplankton need nutrients to survive, develop and reproduce. In the surface ocean, nutrients come from one of several pathways: from the depths of the ocean, from the rivers and from the atmosphere. In the Arabian Sea, there are two important sources of nutrients for the organisms living in the surface layer of the ocean: the nutrient-rich waters coming from below, which occurs along the coast of the Arabian Peninsula, and the desert dust deposited from above. In this study, we show that neither source brings all the necessary nutrients nor brings enough nutrients. Both of these types of inputs are required to understand the distribution of the phytoplankton. If there was no dust deposition in the Arabian Sea, these organisms that represent the first link in the ocean food chain would be half as abundant as they are currently. 


\section{Introduction}

Inorganic nutrients of atmospheric origin (such as nitrogen, phosphorus and iron) can enhance phototrophic, heterotrophic and diazotrophic activities by relieving the macroand/or micro-nutrient limitation encountered at the time of deposition (Duce et al., 1991). Because they can be a significant source of nutrients for the surface ocean, such inputs can impact the pattern of nutrient limitation in the upper ocean (Moore et al., 2013). Atmospheric nutrient inputs to the ocean surface from natural sources (iron and phosphorus from dust inputs) and anthropogenic sources (reactive nitrogen emitted by combustion and agriculture) differ in their spatio-temporal distribution (Duce et al., 1991). The AS is the oceanic region receiving some of the most substantial dust deposition (Jickells et al., 2005), with annual fluxes predicted to be up to $50 \mathrm{~g} \cdot \mathrm{m}^{-2} \cdot \mathrm{yr}^{-1}$ in the northernmost sector. Dense dust plumes occurring with high frequency above the AS are visible from space (e.g., https://earthobservatory.nasa.gov/images/92522/sandy-shamal-season) and have strong interannual variability (Banerjee and Kumar 2016). These natural deposits come from various parts of the Arabian Peninsula, Iraq and arid areas north of the AS and from North Africa (Ackerman and Cox, 1989; Husar et al., 1997). The AS also receives large amounts of anthropogenic bioavailable reactive nitrogen from the Indian sub-continent (Krishnamurti et al., 1998, Singh et al., 2012), and dust and pollutants often appear mixed (Krishnamurti et al., 1998). Atmospheric deposition thus provides a combination of the essential nutrients $\mathrm{N}, \mathrm{P}$, and Fe to the surface waters of the AS.

The seasonal cycle of phytoplankton (from in situ observations, e.g. Barber et al., 2001, and modelling studies, e.g., Keerthi et al., 2017) is characterized by two blooms triggered by two monsoons. Air masses flow in opposite directions during the winter monsoon (active from

December to March) coming from the northeast and the summer monsoon (active from June to September) coming from the southwest. The meteorological conditions during the summer 
monsoon drive coastal upwelling that brings nutrients along the Arabian Peninsula, leading to intense productivity. The winter monsoon is associated with convective mixing north of $15^{\circ} \mathrm{N}$ that entrains nutrients from below and triggers biological activity. Between these seasons, conditions are characterized by lower chlorophyll concentrations, with May being the month with the most oligotrophic conditions (Morrison et al., 1998). The AS is thus characterized by highly contrasting primary production regimes throughout the year, with variations between coastal and offshore areas, from mesotrophic waters along the Arabian Peninsula coast to oligotrophic waters in the centre of the AS, inferred by contrasting spatial/temporal nutrient limitations.

The AS is one of the remaining under-sampled regions of the global ocean where a complete description of the nutrient limitation pattern is lacking (Moore et al., 2013). Nevertheless, previous studies have shown that fixed inorganic nitrogen is generally more limiting than phosphate (Morrison et al., 1998). The question of iron limitation remains open; iron has been reported as a possible limiting nutrient in the AS (Takeda et al., 1995, Wiggert et al. 2006, Moffet et al., 2007), as a limiting nutrient during the summer monsoon over the southern parts of the Omani shelf and in the offshore region (Naqvi et al., 2010) or as only a marginally limiting nutrient (i.e., Koné et al., 2009). To date, there is no evidence based on in situ measurements that such limitation could be temporary or permanent and what region of the AS could be affected. Because $\mathrm{N}_{2}$ fixing organisms (or diazotrophs) have high iron quotas relative to non-diazotrophic phytoplankton (Reuter et al., 1992, Berman-Frank et al., 2001), the input of atmospheric iron to the ocean surface usually stimulates the growth of diazotrophs when enough phosphate is available or when both iron and phosphate are provided by dust (Guieu et al., 2014). The AS should thus represent an ecological niche for diazotrophs. Although available $\mathrm{N}_{2}$ fixation measurements in the AS are still scarce, the data show a large range of fluxes, with the highest $\mathrm{N}_{2}$ fixation rates measured in the shallow $(<100$ 
m) coastal region along India $\left(36000 \mu \mathrm{mol} \mathrm{N} . \mathrm{m}^{-2} \cdot \mathrm{d}^{-1}\right.$, Gandhi et al., 2011), orders of magnitude higher than the few reported rates for the open AS $\left(130 \mu \mathrm{mol} \mathrm{N} . \mathrm{m}^{-2} \cdot \mathrm{d}^{-1}\right.$ maximum rate in the subsurface (Capone et al., 1998)).

Knowledge of dust deposition fluxes and dust composition (in particular, its potential to release dissolved iron, nitrate and phosphate) and the possible effects on the biogeochemistry of the AS have also been little studied until present. Based on dust optical depth and Chla, both derived from satellite data, Banerjee and Kumar (2014) found in rare cases a coincidence between Chla enhancement and the passage of dust storms in the central AS. Combining atmospheric $\mathrm{N}$ fluxes derived from the nitrogen content of aerosols with new production measurements performed during cruises, Singh et al. (2012) concluded that the contribution of new $\mathrm{N}$ from the atmosphere to new production could be at maximum $3 \%$. Clearly both studies emphasized the fact that collocated measurements are needed to better understand/quantify the possible link between atmospheric inputs of new nutrients and productivity, seasonally and over the whole AS.

The spatial and temporal nutrient limitation of the mixed layer ecosystem and the possible role of new nutrients from the atmosphere are thus still not well understood in the AS. In the absence of sufficient in situ co-located measurements informing both spatial and temporal variability, we propose to study the potential of atmospheric nutrient input to stimulate production in the AS by means of a numerical model. We use a state-of-the-art circulation and biogeochemistry model that considers the atmosphere as a source of nutrients to assess the seasonal impact of atmospheric deposition on chlorophyll, new production and $\mathrm{N}_{2}$ fixation in the AS.

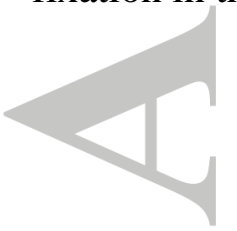




\section{Methods}

\subsection{Ocean Model}

We use an Arabian Sea configuration of the Regional Ocean Modelling System (ROMS)AGRIF (http://www.croco-ocean.org/) similar to that used in recent AS modelling studies by Lachkar et al. (2016, 2018). ROMS is a free-surface, hydrostatic, primitive equation ocean model that uses generalized terrain-following vertical coordinates (Shchepetkin and McWilliams, 2005). We use a rotated-split third-order upstream biased operator to represent advection (Marchesiello et al., 2009). The non-local K-profile parameterization (KPP) scheme is used to represent subgrid vertical mixing (Large et al., 1994). The biogeochemical model is the Pelagic Interaction Scheme for Carbon and Ecosystem Studies (PISCES)v-2 (Aumont et al. 2015), which simulates the lower trophic levels of marine ecosystems (small phytoplankton, diatoms, microzooplankton and mesozooplankton) and the biogeochemical cycles of carbon and the main nutrients (P, N, Fe, and $\mathrm{Si}$ ). This version of PISCES includes new parameterizations (compared to the previous version of Aumont and Bopp, 2006), in particular for $\mathrm{N}_{2}$ fixation and iron chemistry (text $\mathrm{S} 1$ ). In the model, nutrients are provided to the ocean from five different sources: atmospheric dust deposition, rivers, sea ice, sediment mobilization and hydrothermal vents.

\subsection{Atmospheric deposition}

For the atmospheric supply of soluble iron, nitrogen and phosphorus, modelled deposition is based on Brahney et al. (2015) and Chien et al. (2016). Briefly, simulations were conducted using the CAM4 (Community Atmospheric Model); they were driven by interactively calculated winds and the slab ocean model (Neale et al., 2013) and were averages of 4 years, with a one-year spin up discarded. The atmospheric aerosol model includes 3-dimensional transport and wet and dry deposition of gases and aerosols (Mahowald et al., 2006, Lamarque et al., 2011). For nitrogen, the chemistry version was included, which considers ozone and 
organic compounds for preindustrial, current and future simulations (Lamarque et al., 2010). Nitrogen emissions from fires were from the observation-based Global Fire Emissions Database version 3 (GFED3) (van der Werf et al., 2006, Randerson et al., 2013). Dust and wildfire emissions were compared and tuned to observations such as in situ and aerosol optical depths, as described in Ward et al. (2012) and Albani et al. (2014). Total and soluble Fe were modelled, including dust and combustion sources of total and soluble iron (Luo et al., 2008; Chien et al., 2016), while total and soluble phosphorus included dust, combustion, primary biogenic, sea spray and volcanic sources (Mahowald et al., 2008; Brahney et al., 2014; Chien et al., 2016). The annual mean deposition fluxes and their temporal patterns are presented in Figure 1 (monthly climatology: Figure S1). The patterns of both oxidized and reduced atmospheric nitrogen deposition exhibit a strong east to west gradient, illustrating the influence of strong atmospheric inputs from anthropogenic emissions from India to the AS. Although visible all year round, anthropogenic deposition peaks in summer. Phosphate deposition and iron deposition have comparable patterns, as the main source of those elements is dust: deposition peaks in June and July, but deposition is also significant in May, August and September.

For $\mathrm{Si}$, atmospheric deposition is prescribed according to the default module of the PISCES model described in Aumont et al. (2015). Sensitivity tests with/without Si deposition were performed that showed weak effects (not shown), and Si deposition is thus not discussed further in this study. Si deposition is imposed in all simulations that have activated deposition for any of the nutrients considered here $(\mathrm{N}, \mathrm{P}, \mathrm{Fe})$.

\subsection{Experimental design}

The model domain covers the area from $6^{\circ} \mathrm{S}$ to $31^{\circ} \mathrm{N}$ in latitude and from $32^{\circ} \mathrm{E}$ to $78^{\circ} \mathrm{W}$ in longitude with a grid resolution of $1 / 10^{\circ}$, which allows the resolution of a large fraction of the mesoscale variability. The vertical grid consists of 32 layers with enhanced resolution near 
the surface. The bathymetry is derived from the ETOPO2 file provided by the National Geophysical Data Center (Smith and Sandwell, 1997). We use a monthly climatological forcing based on the 6 hourly ECMWF ERA-Interim to provide wind stress, surface heat and freshwater fluxes using a bulk formula (Fairall et al., 2003). Surface temperature and salinity are restored to monthly climatology satellite data (AVHRR-Pathfinder and Aqua-Modis) and World Ocean Atlas (WOA) 2013 data, respectively, using kinematic flux corrections following Barnier et al. (1995). The initial and lateral boundary conditions are derived from the WOA 2013 for biogeochemical tracers (nitrate, phosphate, oxygen, silicic acid) and the Simple Ocean Data Assimilation (SODA) ocean reanalysis for temperature, salinity and currents (Carton and Giese, 2008; Garcia et al., 2013). Following Aumont et al. (2015), other ecological tracers are initialized uniformly to arbitrarily low values, and iron concentrations are set to $0.6 \mathrm{nM}$. The model is spun up for 16 years. We use the model years 17 to 21 for analysis. A brief comparison of PISCES simulated fields based on the all deposition experiment, with some available observations at the surface is presented in the Supporting Information (Figures S2-S6, text S2; temperature (Reynolds et al., 2007); salinity (Zweng et al., 2013); currents (Lumpkin and Johnson, 2013); nitrate and phosphate concentrations (Garcia et al., 2013)).

The sensitivity of the AS biogeochemistry to atmospheric deposition was tested through a series of model experiments with either zero atmospheric deposition or different combinations of atmospheric deposition of soluble Fe, soluble P and $\mathrm{N}$. The seasonal average for the last 5 years simulated by the model in response to the different scenarios was then compared to the 'no deposition' experiment for chlorophyll a, new primary production and nitrogen fixation. 


\section{Impact of atmospheric deposition on chlorophyll concentrations and carbon fixation in surface waters}

We compared a monthly composite satellite image of Chla to the different model experiments. The satellite Chla level-3 data were taken from the GlobColour archive (http://globcolour.info), which is based on the merging of SeaWIFS, MERIS, MODIS, and VIIRS sensors from 1998 to 2014. Regardless of the season, the 'no deposition' and the 'all deposition except iron' experiments fail at properly reproducing the Chla pattern (Figure 2cd), even during the summer monsoon season when the upwelling activity is at a maximum. When deposition of all nutrients or soluble iron only (not shown) are considered, the patterns are found to be very similar to the observations, reproducing both seasonal and spatial variabilities (Figure 2b).

In the 'all deposition' experiment, Chla concentrations are in the right range of the observations but are underestimated during the winter monsoon for the northernmost region of the AS. This underestimation could be in part related to an overestimation of the satellite Chla in the area east of Ormuz. Indeed, Matsushita et al. (2012) identified the Gulf of Oman as an area dominated by case- 2 waters (coastal-type waters characterized by different types of particles in addition to phytoplankton). This comparison clearly indicates that the model simulation is closer to the observations when atmospheric deposition of soluble iron is taken into account and that adding the inputs of phosphate and/or nitrogen does not significantly improve the agreement with the satellite observations. This result likely indicates that the input of atmospheric soluble iron is necessary for phytoplankton to take up available $\mathrm{N}$ and $\mathrm{P}$ and to grow up to levels seen by satellite observations. Interestingly, the stronger effect of atmospheric soluble iron is visible during the upwelling season, confirming the weak inputs of DFe from upwelling. Except during the AM inter-monsoon season, when the effect of atmospheric soluble iron is minimal (maximum contribution $\sim 30 \%$ of the Chla in surface 
waters observed in the eastern AS (Figure S7)), atmospheric soluble iron affects a large area mostly west of $65^{\circ} \mathrm{E}(50 \%-100 \%$ of Chla concentrations). The need for atmospheric iron to sustain the observed in situ Chla concentrations has already been hypothesized by Measures and Vink (1999), but this is the first time that a quantification is proposed, indicating that atmospheric iron plays a major role in carbon fixation in most of the AS and almost all year

\section{long.}

The net primary production (NPP) computed by the model when considering all atmospheric deposition (Figure S8, Table 1: annual mean $669 \mathrm{mgC} \cdot \mathrm{m}^{-2} \cdot \mathrm{d}^{-1}$ ) is in good agreement with regional estimates for the AS derived from the global assessment from Uitz et al., 2008 (569 $\left.\mathrm{mgC} \cdot \mathrm{m}^{-2} \cdot \mathrm{d}^{-1}\right)$.. Our model reproduces well the seasonal variability in the different domains.

When considering the whole domain of study, we show (Table 1) that without soluble atmospheric iron, the NPP would be reduced by $30 \%$ at the annual scale and by $54 \%$ in JJAS. This key role of atmospheric iron likely explains why, when considering only the impact of new $\mathrm{N}$ from the atmosphere, Singh et al. 2012 calculated only a very weak impact of $+3 \%$ on the NPP. The inspection of the nutrient patterns simulated in surface seawater when atmospheric deposition is included indeed shows an opposite pattern between dissolved iron (with concentrations decreasing from east to west in the NE AS) and phosphate and nitrate (with concentrations decreasing from west (upwelling area) to east (Figure S9)). Outside the area influenced by upwelling, phosphate and nitrate concentrations are below 0.4 and $0.8 \mu \mathrm{M}$, respectively, in agreement with in situ measurements (Takeda et al., 1995, Schlitzer et al., 2018). The model results also reflect some seasonality, with the phosphate and nitrate gradient being more marked during the upwelling season. The weak impact of upwelling on DFe in our model experiments can be seen from sections of the model output with no atmospheric deposition (Figure S10): although the input is higher in summer when upwelling is active, the resulting high DFe concentrations are limited to a narrow area close to the 
Arabic Peninsula coast. Such low inputs are likely because upwelling is quite shallow and the very narrow and steep shelf precludes a large input from the sediments. Furthermore, the very intense biological activity and subsequent export very close to the coast preclude significant amounts of iron from being transported efficiently far offshore. Such a limited impact of the upwelling-related input on DFe concentrations has been reported by Measures and Vink (1999), who measured DFe concentrations in upwelled waters of $\sim 1 \mathrm{nM}$. Our model results with no atmospheric deposition are in good agreement with this value (1 $\mathrm{nM}$ rapidly decreasing to $0.1 \mathrm{nM}$ offshore when no deposition is considered (Figure S11)). The DFe in the surface waters of the AS has always been reported in the range 0.1-1 nM (Saager et al., 1989, Takeda et al. 1995, Moffet et al., 2007, Shiozaki et al., 2014). The most recent DFe vertical profile (Schlizer et al., 2018) during the winter monsoon at $69^{\circ} \mathrm{E}-16.75^{\circ} \mathrm{N}$ is comparable to our model section at $20^{\circ} \mathrm{N}$ for the same longitude (Figure S11): the model provides the correct order of magnitude of the surface concentrations and reproduces well the shape of the vertical profiles. Our results suggest that in the absence of dust deposition, carbon fixation by autotrophs is limited by the availability of iron, meaning that there is a potential limitation linked to dust occurrence.

\section{Effect of dust deposition on $\mathrm{N}_{2}$ fixation}

$\mathrm{N}_{2}$ fixation rate measurements are scarce in the AS and differ by orders of magnitude between extremely high values in the very coastal shallow area along India (e.g., $~ 100$ to

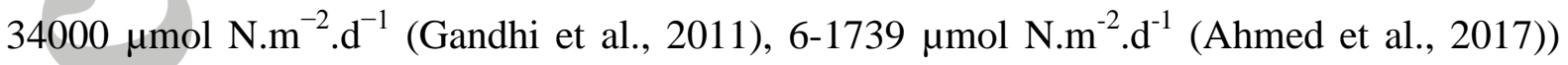
and moderate ones in the open sea. In winter in the open AS, Shiozaki et al. 2014 measured at 3 stations in our domain at $70^{\circ} \mathrm{E} \mathrm{N}_{2}$ fixation rates of $25-47 \mu \mathrm{mol} \mathrm{N} \cdot \mathrm{m}^{-2} \cdot \mathrm{d}^{-1}$, with a rapid decrease $\left(6-17 \mathrm{~N} \mathrm{~m}^{-2} \cdot \mathrm{d}^{-1}\right)$ at the stations south of our domain. During a campaign in May along a transect along $65^{\circ} \mathrm{E}$ through the central basin of the AS, Capone et al. (1998) found higher rates in the upper $0.5 \mathrm{~m}\left(130 \mu \mathrm{mol} \mathrm{N} . \mathrm{m}^{-2} \cdot \mathrm{d}^{-1}\right.$ max rate $)$ in a Trichodesmium bloom at 
their station located at $65^{\circ} \mathrm{E}-10^{\circ} \mathrm{N}$ but a maximum rate of $36 \mu \mathrm{mol} \mathrm{N} \cdot \mathrm{m}^{-2} \cdot \mathrm{d}^{-1}$ in the waters between 0.5 and $100 \mathrm{~m}$ at the same station. Our modelled rates when including atmospheric deposited iron show that overall $\mathrm{N}_{2}$ fixation rates over the AS (Figure 3) are moderate compared to other oceanic regions, such as the western tropical South Pacific, where the $\mathrm{N}_{2}$ fixation process has been shown to be a major path for new nitrogen (Caffin et al., 2018). In the AS, maximum rates are on the order of $30 \mu \mathrm{mol} \mathrm{N} \cdot \mathrm{m}^{-2} \cdot \mathrm{d}^{-1}$ in April/May (Table 1, Figure S12), in good agreement with the available in situ measurements for the same season in the same area $\left(70^{\circ} \mathrm{E}-10^{\circ} \mathrm{N}\right)$ (Capone et al., 1998). The simulation clearly indicates that atmospheric soluble iron supports most $\mathrm{N}_{2}$ fixation (Table 1).

$\mathrm{N}_{2}$ fixation rates are higher east of $60^{\circ} \mathrm{E}$, corresponding to higher soluble iron concentrations in surface waters and lower $\mathrm{NO}_{3}$ surface concentrations (Figure $\mathrm{S} 11$ ). In the western open AS, observations are available in coastal waters of Tanzania (Lugomela et al., 2002),) with the lowest rates $\left(\sim 1 \mu \mathrm{mol} \mathrm{N} \cdot \mathrm{m}^{-2} \cdot \mathrm{d}^{-1}\right)$ measured between June and October and the highest rates $\left(14 \mu \mathrm{mol} \mathrm{N} \cdot \mathrm{m}^{-2} \cdot \mathrm{d}^{-1}\right)$ measured in December-April. Our model predicts low $\mathrm{N}_{2}$ fixation rates $\left(0-<5 \mu \mathrm{mol} \mathrm{N} \cdot \mathrm{m}^{-2} \cdot \mathrm{d}^{-1}\right)$ except during the spring inter-monsoon season, when $\mathrm{N}_{2}$ fixation is observed in the whole domain with rates on the order of $15 \mu \mathrm{mol} \mathrm{N} \cdot \mathrm{m}^{-2} \cdot \mathrm{d}^{-1}$, and during summer in the northernmost part of the AS (Gulf of Oman) with rates on the order of 30 $\mu$ mol N.m ${ }^{-2} \cdot d^{-1}$ (Figure S12). This interesting feature could be explained by the very high temperatures (32 degrees) of surface waters during summer (June-September) in that area, as evidenced by AVHRR satellite measurements (Reynolds et al., 2007). However, this feature can be an artefact of the model parameterization of $\mathrm{N}_{2}$ fixation, which predicts a continuous increase in $\mathrm{N}_{2}$ fixation under nutrient-replete conditions with temperature, whereas $\mathrm{N}_{2}$ fixation has been suggested to be at a maximum at $27.5^{\circ} \mathrm{C}$ and to decrease above this temperature (Breitbarth et al., 2007). 
Averaged over the whole domain, we calculated from our modelling that $\mathrm{N}_{2}$ fixation represents only a negligible contribution of the nitrogen demand of NPP $(<1 \%)$ (Table 1$)$. The comparison between two of the annually averaged external sources of new nitrogen across the AS (atmospheric deposition $\left(265 \mathrm{~kg} \mathrm{~N} \cdot \mathrm{km}^{-2} \cdot \mathrm{yr}^{-1}\right.$ (Figure 1) $=52 \mu \mathrm{mol} \mathrm{N} . \mathrm{m}^{-2} \cdot \mathrm{d}^{-1}$ ) and $\mathrm{N}_{2}$ fixation (from the model when the atmospheric iron deposition is taken into account $=$

$11.4 \mu \mathrm{mol} \mathrm{N} \cdot \mathrm{m}^{-2} \cdot \mathrm{d}^{-1}$ (Figure 3)) shows that $\mathrm{N}_{2}$ fixation represents only $20 \%$ of the total. $\mathrm{N}_{2}$ fixation is likely not a major pathway for new nitrogen at the scale of the whole AS.

\section{Conclusions}

During the summer monsoon, the active upwelling along the coast of the Arabian Peninsula fuels increased $\mathrm{N}$ and $\mathrm{P}$ in the upper waters of the AS. These waters have low concentrations of iron, and iron from dust is necessary to allow phytoplankton to uptake the major nutrients and fix carbon. Without atmospheric iron deposition, net primary production during the 4 months of upwelling activity would be lowered by more than $50 \%$ at the scale of the whole Arabian Sea. Thus, there is a potential Fe limitation for autotrophs linked to dust occurrence in the Arabian Sea. Atmospheric iron, in particular, explains most of the $\mathrm{N}_{2}$ fixation, but this process supports only a negligible fraction of primary production. Most of the fertilization by atmospheric iron impacts non-diazotroph species such as diatoms, phytoplankters with high iron requirements that are abundant in the AS (Sawant and Madhupratap, 1996).

In the future, several factors could contribute to changes in biological production in this area. The Indian Ocean and particularly the AS are encountering rapid warming, likely enhancing stratification and decreasing marine primary production (Roxy et al., 2016). On the contrary, other perturbations, such as regional wind changes, could increase productivity by intensifying upwelling (Lachkar et al., 2018). The future atmospheric depositions in this region are not well constrained, especially from land use sources and desert dust (e.g., Ward et al., 2014). Increases in desert dust due to aridity or changes in surface winds are possible 
(e.g., Ward et al., 2014, Evan et al. 2016,) and are likely to control both iron and phosphorus deposition (Mahowald et al., 2008, 2017). Depending on the respective amplitudes of changes in each forcing, dust deposits could play an increased role compared to the present state. The likely increase in dust deposits is therefore an additional source of potential change in primary productivity.

\section{Acknowledgements}

The readers can access the data supporting the analysis and conclusions here: doi:10.5281/zenodo.2589007. Support for this research has come from the Center for Prototype Climate Modeling (CPCM) at New York University Abu Dhabi (NYUAD).

This research was carried out on high-performance computing (HPC) resources at NYUAD. We thank Benoit Marchand, Muataz Al Barwani and the whole NYUAD HPC team for technical support. We thank D. Capone and W. Koeve for their kind help to improve this manuscript.

\section{References}

Ackerman, S. A., \& Cox, S. K. (1989), Surface weather observations of atmospheric dust over the southwest summer monsoon region. Meteorology and Atmospheric Physics, 41(1), 19-34.

Ahmed, A., Gauns, M., Kurian, S., Bardhan, P., Pratihary, A., Naik, H. et al. (2017), Nitrogen fixation rates in the eastern Arabian Sea. Estuarine, Coastal and Shelf Science, 191, 74-83. 
Albani, S., Mahowald, N., Perry, A., Scanza, R., Zender, C. \& Flanner, M. G. (2014), Improved representation of dust size and optics in the CESM, J. Adv. Model. Earth Syst., 6, doi:10.1002/2013MS000279

Aumont, O. \& Bopp, L. (2006), Globalizing results from ocean in-situ iron fertilization studies, Global Biogeochem. Cy., 20, GB2017, doi:10.1029/2005GB002591

Aumont, O., Éthé, C., Tagliabue, A., Bopp, L., \& Gehlen, M. (2015), PISCES-v2: an ocean biogeochemical model for carbon and ecosystem studies. Geoscientific Model Development, 8(8), 2465.

Banerjee, P., \& Kumar, S. (2014), Dust-induced episodic phytoplankton blooms in the Arabian Sea during winter monsoon. Journal of Geophysical Research: Oceans, 119(10), 7123-7138

Barber, R. T., Marra, J., Bidigare, R. C., Codispoti, L. A., Halpern, D., Johnson, Z., ... \& Smith, S. L. (2001). Primary productivity and its regulation in the Arabian Sea during 1995. Deep Sea Research Part II: Topical Studies in Oceanography, 48(6-7), 11271172.

Barnier, B., Siefridt, L., and Marchesiello, P. (1995), Thermal forcing for a global ocean circulation model using a three-year climatology of ecmwf analyses, J. Marine Syst., $6,363-380$.

Berman-Frank, I., Cullen, J. T., Shaked, Y., Sherrell, R. M. \& Falkowski, P. G. (2001), Iron availability, cellular iron quotas, and nitrogen fixation in Trichodesmium. Limnol Oceanogr. 46, 1249-1260

Brahney, J., Mahowald, N., Ward, D. S., Ballantyne, A. P. \& Neff, J. C. (2015), Is atmospheric phosphorus pollution altering global alpine Lake stoichiometry?, Global Biogeochem. Cycles, 29(9), doi:10.1002/2015GB005137 
Breitbarth E., Oschlies A. \& LaRoche J. (2007), Physiological constraints on the global distribution of Trichodesmium-effect of temperature on diazotrophy Biogeosciences, $4(1)$, pp. 53-61

Caffin, M., Moutin, T., Foster, R. A., Bouruet-Aubertot, P., Doglioli, A. M., Berthelot, H., .. \& Gimenez, A. (2018). N 2 fixation as a dominant new N source in the western tropical South Pacific Ocean (OUTPACE cruise). Biogeosciences, 15(8), 2565-2585, https://doi.org/10.5194/bg-15-2565-2018

Capone, D. G., Subramaniam, A., Montoya, J. P., Voss, M., Humborg, C., Johansen, A. M. et al. (1998), An extensive bloom of the N2-fixing cyanobacterium Trichodesmium erythraeum in the central Arabian Sea. Marine Ecology Progress Series, 172, 281-292.

Chien, C.-T., Mackey, K. R. M., Dutkiewicz, S., Mahowald, N. M., Prospero, J. M. \& Paytan, A. (2016), Effects of African dust deposition on phytoplankton in the western tropical Atlantic Ocean off Barbados, Global Biogeochem. Cycles, 30(5), doi:10.1002/2015GB005334.

Duce, R. A., Liss, P. S., Merrill, J. T., Atlas, E. L., Buat-Menard, P., Hicks, B. B. et al. (1991), The atmospheric input of trace species to the world ocean. Global biogeochemical Cycles, 5(3), 193-259.

Evan, A., Flamant, C., Gaetani, M. and Guichard, F. (2016), The past, present and future of African dust, Nature, 531, 493-495

Gandhi N., A. Singh, S. Prakash, R. Ramesh, M. Raman, M.S. Sheshshayee \& S. Shetye (2011), First direct measurements of N2 fixation during a Trichodesmium bloom in the eastern Arabian Sea, Glob. Biogeochem. Cy, 25 (4) 
Garcia, H. E., Locarnini, R. A., Boyer, T. P., Antonov, J. I., Baranova, O. K., Zweng, M. M., ... \& Levitus, S. (2013). World ocean atlas 2013. Volume 4, Dissolved inorganic nutrients (phosphate, nitrate, silicate).

Guieu C., O. Aumont, A. Paytan, L. Bopp, C.S. Law, N. Mahowald et al. (2014), The significance of episodicity in atmospheric deposition to Low Nutrient Low Chlorophyll regions, Global Biogeochemical Cycles, 2014, DOI: $10.1002 / 2014 \mathrm{~GB} 004852$

Husar, R. B., Prospero, J. M., \& Stowe, L. L. (1997), Characterization of tropospheric aerosols over the oceans with the NOAA advanced very high resolution radiometer optical thickness operational product. Journal of Geophysical Research: Atmospheres, 102(D14), 16889-16909.

Jickells, T. D., An, Z. S., Andersen, K. K., Baker, A. R., Bergametti, G., Brooks, N. et al. (2005), Global iron connections between desert dust, ocean biogeochemistry, and climate. Science, 308(5718), 67-71.

Keerthi, M. G., Lengaigne, M., Lévy, M., Vialard, J., Parvathi, V., Montégut, C. D. B. et al. (2017), Physical control of interannual variations of the winter chlorophyll bloom in the northern Arabian Sea. Biogeosciences, 14(15), 3615-3632.

Koné, V., Aumont, O., Lévy, M., \& Resplandy, L. (2009), Physical and biogeochemical controls of the phytoplankton seasonal cycle in the Indian Ocean: A modeling study. Indian Ocean biogeochemical processes and ecological variability, volume 185, 350pp. https://doi.org/10.1029/2008GM000700, Book Series:Geophysical Monograph Series

Krishnamurti, T. N., Jha, B., Prospero, J., Jayaraman, A., \& Ramanathan, V. (1998), Aerosol and pollutant transport and their impact on radiative forcing over the tropical 
Indian Ocean during the January-February 1996 pre-INDOEX cruise. Tellus B: Chemical and Physical Meteorology, 50(5), 521-542.

Lachkar, Z., Lévy, M., \& Smith, S. (2018), Intensification and deepening of the Arabian Sea oxygen minimum zone in response to increase in Indian monsoon wind intensity. Biogeosciences, 15(1).

Lachkar, Z., Smith, S., Lévy, M., \& Pauluis, O. (2016), Eddies reduce denitrification and compress habitats in the Arabian Sea, Geophys. Res. Lett., 43, 9148-9156.

Lamarque, J. F., Bond, T. C., Eyring, V., Granier, C., Heil, A., Klimont, Z. et al. (2010), Historical (1850-2000) gridded anthropogenic and biomass burning emissions of reactive gases and aerosols: methodology and application. Atmospheric Chemistry and Physics, 10(15), 7017-7039.

Lamarque, J. F., Emmons, L. K., Hess, P. G., Kinnison, D. E., Tilmes, S., Vitt, F. et al. (2012), CAM-chem: Description and evaluation of interactive atmospheric chemistry in the Community Earth System Model, Geosci. Model Dev., 5(2), 369-411, doi:10.5194/gmd-5-369-2012

Lamarque, J. F., G. P. Kyle, M. Meinshausen, K. Riahi, S. Smith, D. P. van Vuuren et al. (2011), Global and regional evolution of short-lived radiatively-active gases and aerosols in the Representative Concentration Pathways, Clim. Change, 109, 191-212. doi:10.1007/s10584-011-0155-0

Large,W. G., McWilliams, J. C., \& Doney, S. C. (1994), Oceanic vertical mixing: A review and a model with a nonlocal boundary layer parameterization, Rev. Geophys., $32,363-403$. 
Lévy, M., Shankar, D., André, J. M., Shenoi, S. S. C., Durand, F., \& de Boyer Montégut, C. (2007), Basin- wide seasonal evolution of the Indian Ocean's phytoplankton blooms. Journal of Geophysical Research: Oceans, 112(C12)

Lugomela, C., T. J. Lyimo, I. Bryceson, A. K. Semesi and B. Bergman (2002), Trichodesmium in coastal waters of Tanzania: diversity, seasonality, nitrogen and carbon fixation, Hydrobiologia 477(1-3), 1-13.

Lumpkin, R., \& Johnson, G. C. (2013). Global ocean surface velocities from drifters: Mean, variance, El Niño-Southern Oscillation response, and seasonal cycle. Journal of Geophysical Research: Oceans, 118(6), 2992-3006.

Luo, C., Mahowald, N., Bond, T., Chuang, P. Y., Artaxo, P., Siefert, R. et al. (2008), Combustion iron distribution and deposition, Global Biogeochem. Cycles, 22(GB1012), 1-17, doi:10.1029/2007GB002964

Mahowald, N. M., D. Muhs, Levis, S., Rasch, P. J., Yoshioka, M., Zender, C. S. et al. (2006), Change in atmospheric mineral aerosols in response to climate: last glacial period, pre-industrial, modern and doubled-carbon dioxide climates, J. Geophys. Res., 111(10), D10202, doi:10.1029/2005JD006653, doi:10.1029/2005JD006653

Mahowald, N. M., Scanza, R., Brahney, J., Goodale, C. L., Hess, P. G., Moore, J. K. \& Neff, J. (2017), Aerosol Deposition Impacts on Land and Ocean Carbon Cycles, Curr. Clim. Chang. Reports, 3(1), 16-31, doi:10.1007/s40641-017-0056-Z

Mahowald, N., Engelstaedter, S., Luo, C., Sealy, A., Artaxo, P., Benitez-Nelson, C. et al. (2009), Atmospheric Iron deposition: Global distribution, variability and human perturbations, Annu. Rev. Mar. Sci., 1, 245-278, doi:10.1146/annurev/marine.010908.163727. 
Mahowald, N., Jickells, T. D., Baker, A. R., Artaxo, P., Benitez-Nelson, C. R., Bergametti, G. et al. (2008), Global distribution of atmospheric phosphorus sources, concentrations and deposition rates, and anthropogenic impacts (DOI 10.1029/2008GB003240). Global Biogeochemical Cycles, 22(4).

Marchesiello, P., Debreu, L., \& Couvelard, X. (2009) Spurious diapycnal mixing in terrain-following coordinate models: The problem and a solution, Ocean Modell., 26, $156-169$.

Matsushita, B., Yang, W., Chang, P., Yang, F., \& Fukushima, T. (2012), A simple method for distinguishing global Case-1 and Case-2 waters using SeaWiFS measurements. ISPRS journal of photogrammetry and remote sensing, 69, 74-87.

Measures, C. I., \& Vink, S. (1999), Seasonal variations in the distribution of Fe and Al in the surface waters of the Arabian Sea. Deep Sea Research Part II: Topical Studies in Oceanography, 46(8-9), 1597-1622.

Moffett, J. W., Goepfert, T. J., \& Naqvi, S. W. A. (2007), Reduced iron associated with secondary nitrite maxima in the Arabian Sea. Deep Sea Research Part I: Oceanographic Research Papers, 54(8), 1341-1349.

Moore, C. M., Mills, M. M., Arrigo, K. R., Berman-Frank, I., Bopp, L., Boyd, P. W. et al. (2013), Processes and patterns of oceanic nutrient limitation. Nature Geoscience, 6(9), 701.

Morrison, J. M., Codispoti, L. A., Gaurin, S., Jones, B., Manghnani, V., \& Zheng, Z. (1998), Seasonal variation of hydrographic and nutrient fields during the US JGOFS Arabian Sea Process Study. Deep Sea Research Part II: Topical Studies in Oceanography, 45(10-11), 2053-2101. 
Naqvi, S. W. A., Moffett, J. W., Gauns, M., Narvekar, P. V., Pratihary, A. K., Naik, H. et al. (2010), The Arabian Sea as a high-nutrient, low-chlorophyll region during the late Southwest Monsoon, Biogeoscences, 7: 2091-2100, 2010.

Neale, R., Richter, J., Park, S., Lauritzen, P., Vavrus, S., Rasch, P. \& Zhang, M. (2013), The mean climate of the Community Atmosphere Model (CAM4) in forced SST and fully copled experiments, J. Clim., 26(14), 5150-5168; doi:10.1175/jcli-d-1200236.1.

Randerson, J. T., G. R. van der Werf, L. Giglio, G. J. Collatz, \& P. S. Kasibhatla. (2013), Global fire emissions database, Version 3 (GFEDv3.1).

Resplandy, L., Lévy, M., Madec, G., Pous, S., Aumont, O., \& Kumar, D. (2011), Contribution of mesoscale processes to nutrient budgets in the Arabian Sea. Journal of Geophysical Research: Oceans (1978-2012), 116(C11).

Reynolds, R. W., T. M. Smith, C. Liu, D. B. Chelton, K. S. Casey, \& M. G. Schlax (2007), Daily high-resolution blended analyses for sea surface temperature. J. Climate, 20, $5473-5496$.

Risien, C. M. and Chelton, D. B. (2008), A global climatology of surface wind and wind stress fields from eight years of QuikSCAT scatterometer data, J. Phys. Oceanogr., $38,2379-2413$.

Roxy, M. K., Modi, A., Murtugudde, R., Valsala, V., Panickal, S., Kumar, S. P. et al. (2016), A reduction in marine primary productivity driven by rapid warming over the tropical Indian Ocean. Geophysical Research Letters, 43(2), 826-833.

Rueter, J. G., Hutchins, D. A., Smith, R. W. \& Unsworth, N. L. (1992), Iron nutrition of Trichodesmium in Marine pelagic cyanobacteria: Trichodesmium and other Diazotrophs 289-306 (Springer) 
Saager, P. M., De Baar, H. J., \& Burkill, P. H. (1989), Manganese and iron in Indian Ocean waters. Geochimica et Cosmochimica Acta, 53(9), 2259-2267.

Sawant, S.S.; Madhupratap, M. (1996), Seasonality and composition of phytoplankton in the Arabian Sea, Current Science, Vol.71; 869-873p

Schlitzer, R., Anderson, R. F., Dodas, E. M., Lohan, M., Geibert, W., Tagliabue, A. et al. (2018), The GEOTRACES Intermediate Data Product 2017. Chemical Geology, 493, 210-223.

Shchepetkin and McWilliams, 2005 Shchepetkin, A. F. and McWilliams, J. C. (2005), The regional oceanic modeling system (ROMS): a split-explicit, free-surface, topographyfollowing-coordinate oceanic model, Ocean Modell., 9, 347-404, 2005.

Shiozaki T., M. Ijichi, T. Kodama, S. Takeda \& K. Furuya, (2014), Heterotrophic bacteria as major nitrogen fixers in the euphotic zone of the Indian Ocean, Glob. Biogeochem. Cycles, 28, pp. 1096-1110, 10.1002/2014GB004886

Singh, A., Gandhi, N., \& Ramesh, R. (2012), Contribution of atmospheric nitrogen deposition to new production in the nitrogen limited photic zone of the northern Indian Ocean. Journal of Geophysical Research: Oceans, 117(C6).

Takeda, S., Kamatani, A., \& Kawanobe, K. (1995), Effects of nitrogen and iron enrichments on phytoplankton communities in the northwestern Indian Ocean. Marine Chemistry, 50(1), 229-241.

Uitz, J., Huot, Y., Bruyant, F., Babin, M., \& Claustre, H. (2008), Relating phytoplankton photophysiological properties to community structure on large scales. Limnology and Oceanography, 53(2), 614-630. 
van der Werf, G. R., Randerson, J. T., Giglio, L., Collatz, G. J., Kasibhatla, P. S. \& Arellano Jr., A. F. (2006), Interannual variability in global biomass burning emissions from 1997-2004, Atmos. Chem. Phys., 6, 3423-3441, doi: 10.5194/acp-6-3423-2006.

Van Vuuren, D. P., Edmonds, J., Kainuma, M., Riahi, K., Thomson, A., Hibbard, K. et al. (2011), The representative concentration pathways: an overview. Climatic change, 109(1-2), 5 .

Ward, D. S. S., Mahowald, N. M. M. \& Kloster, S. (2014), Potential climate forcing of land use and land cover change, Atmos. Chem. Phys., 14(23), 12701-12724, doi:10.5194/acp-14-12701-2014.

Ward, D. S., Kloster, S., Mahowald, N. M., Rogers, B. M., Randerson, J. T. \& Hess, P. G. (2012), The changing radiative forcing of fires: Global model estimates for past, present and future, Atmos. Chem. Phys., 12(22), doi:10.5194/acp-12-10857-2012.

Wiggert, J. D., Murtugudde, R. G., \& Christian, J. R. (2006), Annual ecosystem variability in the tropical Indian Ocean: Results of a coupled bio-physical ocean general circulation model. Deep Sea Research Part II: Topical Studies in Oceanography, 53(5-7), 644-676.

Zweng, M. M., Reagan, J. R., Antonov, J. I., Locarnini, R. A., Mishonov, A. V., Boyer, T. P., ... \& Biddle, M. M. (2013). World ocean atlas 2013. Volume 2, Salinity.

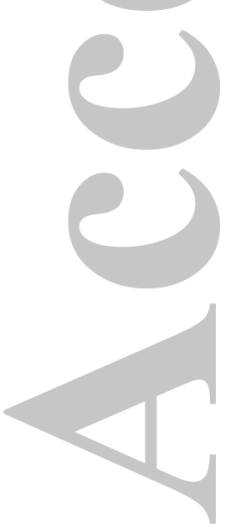


Table 1. Average impact over the whole AS of atmospheric deposition on net primary production (NPP) and nitrogen fixation (N2-Fix) at the seasonal and annual scales.

\begin{tabular}{|c|c|c|c|c|c|c|c|}
\hline & & units & DJFM & AM & JJAS & ON & $\begin{array}{c}\text { annual } \\
\text { mean }\end{array}$ \\
\hline & no deposition (i) & \multirow{3}{*}{$\begin{array}{c}\mathrm{mgC} \mathrm{m} \mathrm{m}^{-2} \mathrm{~d}^{-1} \\
\left(\mu \mathrm{mol} \mathrm{N} \mathrm{m} \mathrm{m}^{-2}\right. \\
\left.\mathrm{d}^{-1}\right)\end{array}$} & $498(6265)$ & $\begin{array}{c}451 \\
(5672) \\
\end{array}$ & $\begin{array}{c}554 \\
(7183) \\
\end{array}$ & $\begin{array}{c}521 \\
(6564) \\
\end{array}$ & $\begin{array}{c}513 \\
(6447) \\
\end{array}$ \\
\hline & all deposition (ii) & & $607(7632)$ & $\begin{array}{c}449 \\
(5654)\end{array}$ & $\begin{array}{c}855 \\
(10756) \\
\end{array}$ & $\begin{array}{c}641 \\
(8068)\end{array}$ & $\begin{array}{c}669 \\
(8416)\end{array}$ \\
\hline \multirow[t]{3}{*}{ NPP } & $\begin{array}{l}\text { all deposition } \\
\text { except iron (iii) }\end{array}$ & & $511(6422)$ & $\begin{array}{c}464 \\
(5842)\end{array}$ & $\begin{array}{c}569 \\
(7163)\end{array}$ & $\begin{array}{c}532 \\
(6686)\end{array}$ & $\begin{array}{c}526 \\
(6616)\end{array}$ \\
\hline & $\begin{array}{l}\text { NPP change (ii- } \\
\text { i) }\end{array}$ & \multirow{2}{*}{$\%$} & 22 & 0 & 54 & 23 & 30 \\
\hline & $\begin{array}{l}\text { NPP change (iii- } \\
\text { i) }\end{array}$ & & 3 & 3 & 3 & 2 & 2.5 \\
\hline \multirow{4}{*}{$\begin{array}{l}\mathrm{N}_{2^{-}} \\
\text {Fix }\end{array}$} & no deposition (i) & \multirow{2}{*}{$\underset{\mathrm{d}^{-1}}{\mu \mathrm{mol} \mathrm{N} \mathrm{m}^{-2}}$} & 2.5 & 5.9 & 2.9 & 2.7 & 3.2 \\
\hline & all deposition (ii) & & 8.2 & 17.4 & 11.2 & 12.4 & 11.4 \\
\hline & $\begin{array}{l}\mathrm{N}_{2} \text { fix change } \\
\text { (ii-i) }\end{array}$ & \multirow{2}{*}{$\%$} & 228 & 194 & 286 & 359 & 256 \\
\hline & $\begin{array}{l}\mathrm{N}_{2} \text { fix: NPP for } \\
\text { all deposition }\end{array}$ & & 0.11 & 0.31 & 0.10 & 0.15 & 0.14 \\
\hline
\end{tabular}

\% change: [(ii) - (i)] $\times$ 100/(i) 
(a) Atmospheric $\mathrm{N}$ deposition
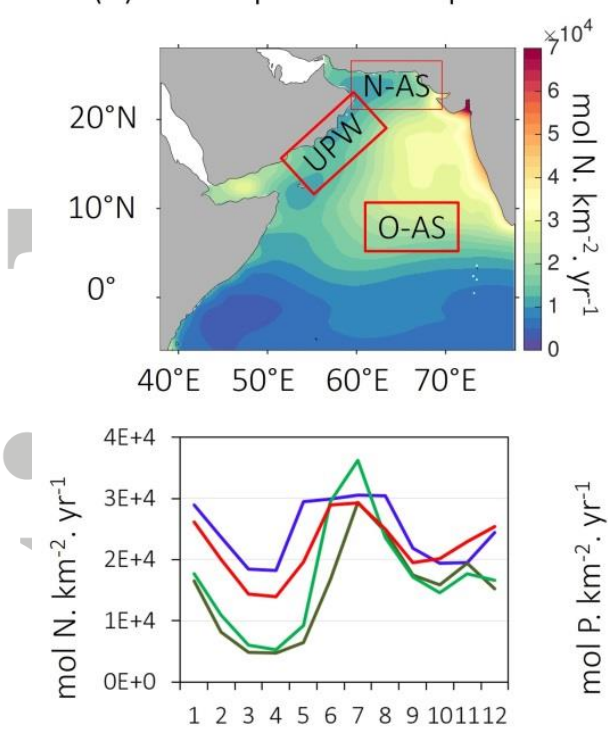

(b) Atmospheric P deposition
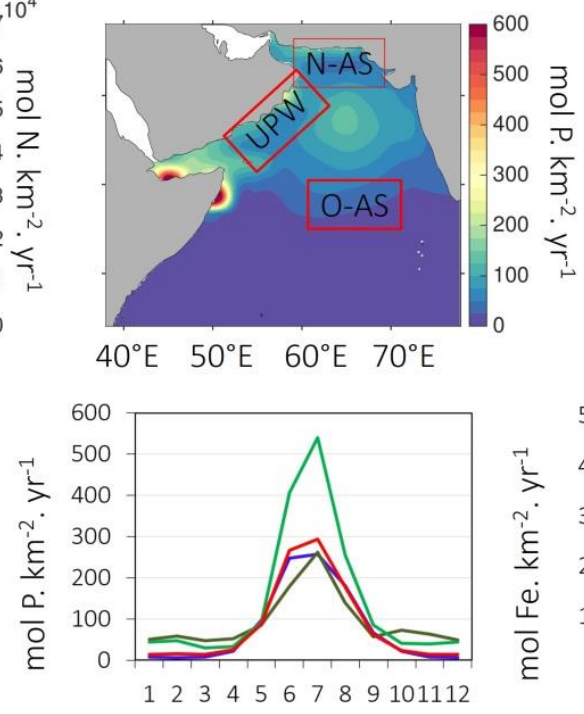

(c) Atmospheric Fe deposition

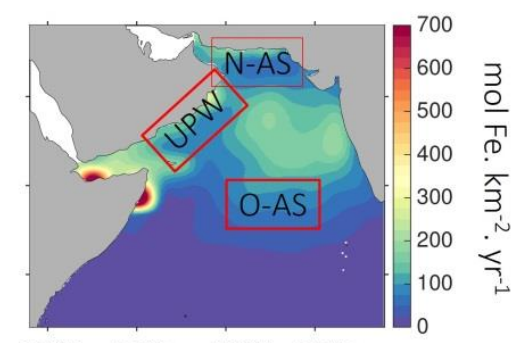

$40^{\circ} \mathrm{E} \quad 50^{\circ} \mathrm{E} \quad 60^{\circ} \mathrm{E} \quad 70^{\circ} \mathrm{E}$

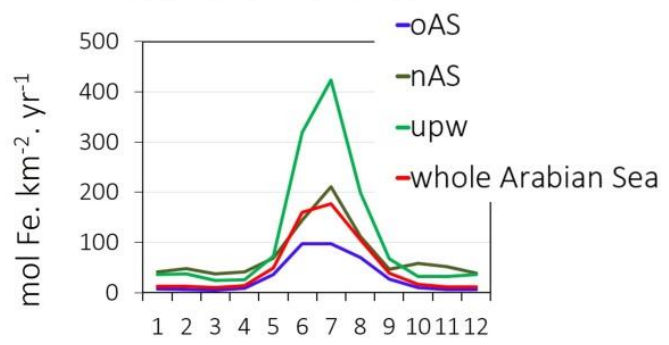

Figure 1. Annual deposition patterns in mol.km-2 $\mathrm{yr}^{-1}$ of a) $\mathrm{N}$, b) soluble phosphorus and c) soluble Fe (upper panel) and the corresponding flux as a function of time (bottom panel) over the whole AS and over three sub-domains (red boxes) characterizing distinct regimes: O-AS: oligotrophic area of the open AS; N-AS: northern AS where the winter monsoon bloom occurs; UPW: upwelling area. 
(a) Satellite
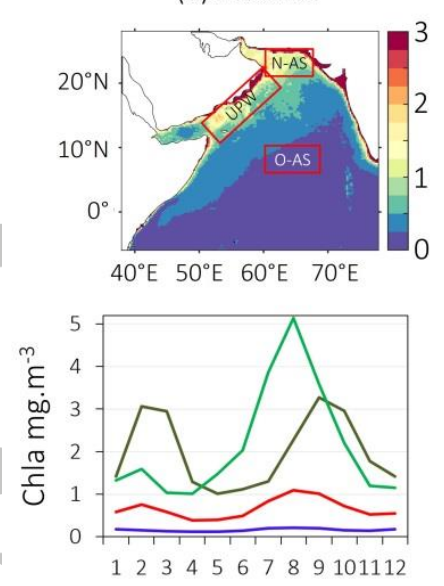

(b) all deposition
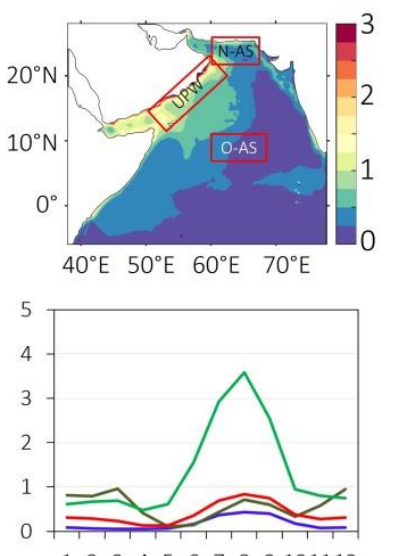

(c) no deposition

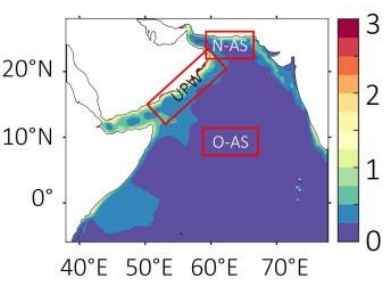

$40^{\circ} \mathrm{E} \quad 50^{\circ} \mathrm{E} \quad 60^{\circ} \mathrm{E} \quad 70^{\circ} \mathrm{E}$

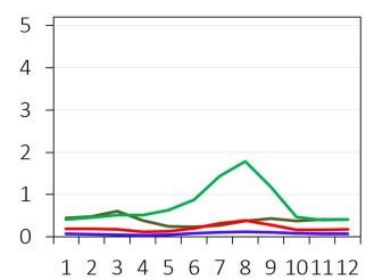

(d) all deposition except iron
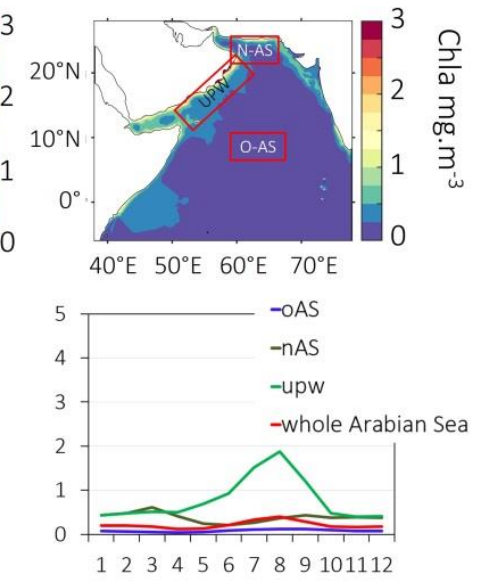

Figure 2. Annual patterns of Chla $\left(\mathrm{mg}^{-\mathrm{m}^{-3}}\right)$ in a) satellite data and simulation with b) all deposition, c) zero deposition and d) all deposition except Fe (upper panel) and the corresponding average Chla concentrations averaged as a function of time (bottom panel) over the AS and in O-AS: Open Arabian Sea; N-AS: Northern Arabian Sea; UPW: upwelling region.

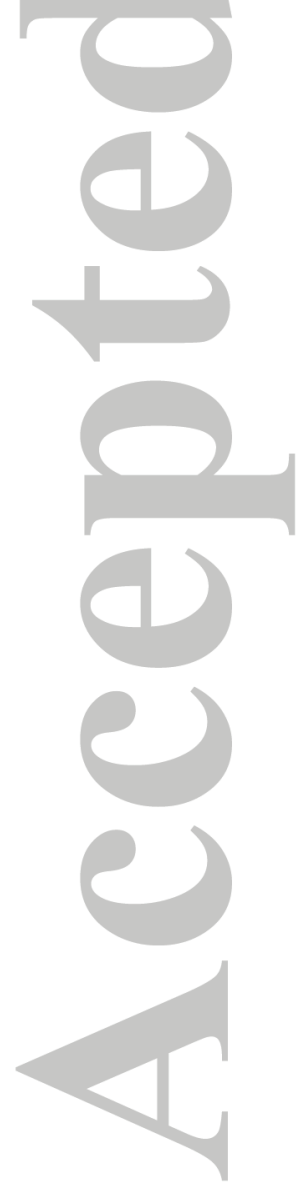


(b) all deposition
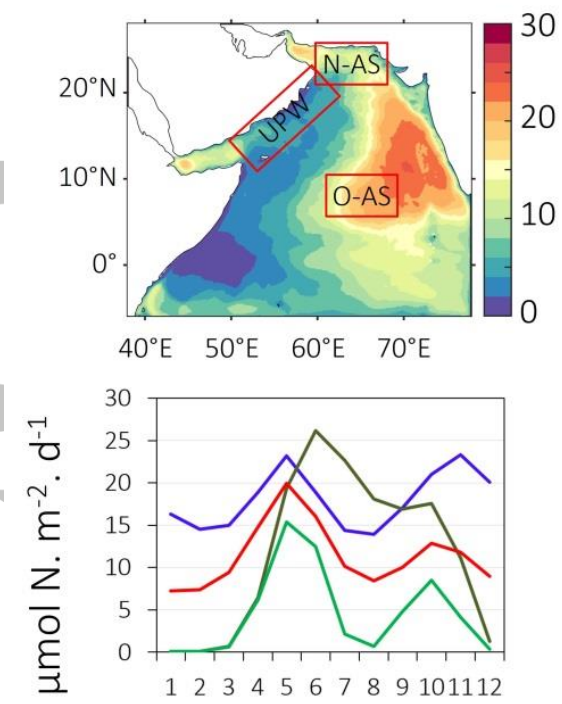

(c) no deposition
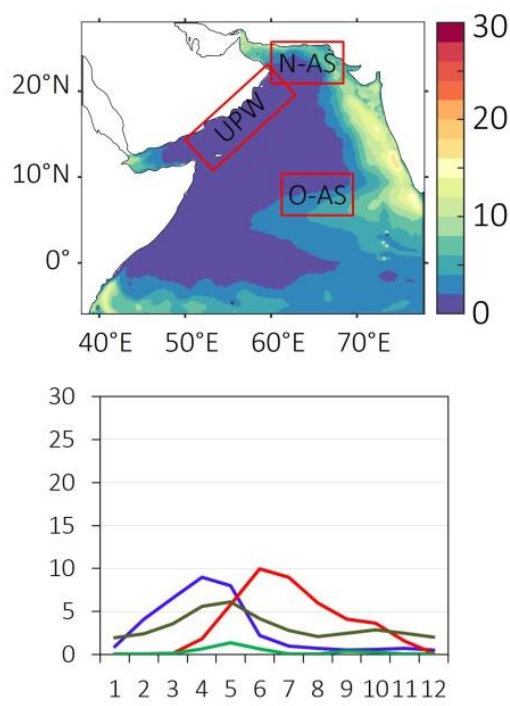

(d) all deposition except iron
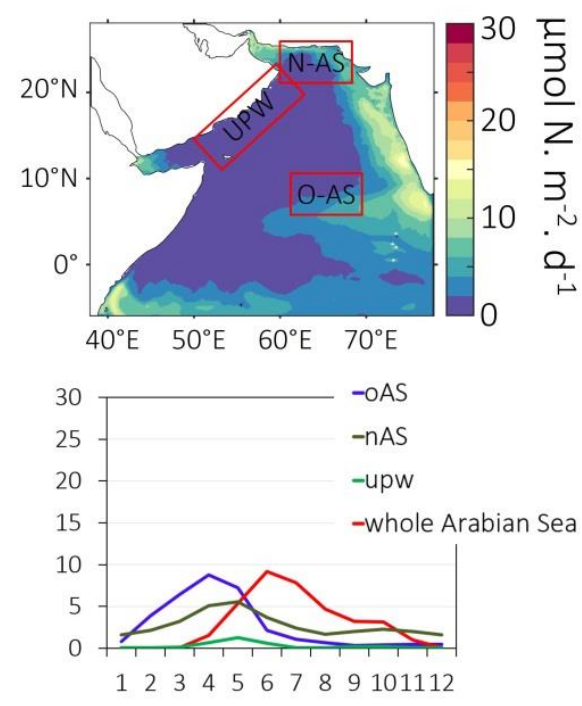

Figure 3. The seasonal cycle of $\mathrm{N}_{2}$ fixation $\left(\mu \mathrm{mol} \mathrm{N} \cdot \mathrm{m}^{-2} \cdot \mathrm{d}^{-1}\right.$ ) in simulations with a) all deposition, b) no deposition and c) all deposition except Fe (upper panel) and the corresponding $\mathrm{N}_{2}$ fixation rates averaged over the whole $\mathrm{AS}$ as a function of time (bottom panel) and in O-AS: Open Arabian Sea; N-AS: Northern Arabian Sea; UPW: upwelling region. 